\title{
Model reactions and natural occurrence of furans from hypersaline environments
}

\author{
T. Krause ${ }^{1}$, C. Tubbesing ${ }^{1}$, K. Benzing ${ }^{2}$, and H. F. Schöler ${ }^{1}$ \\ ${ }^{1}$ Institute of Earth Sciences, University of Heidelberg, Heidelberg, Germany \\ ${ }^{2}$ Institute of Inorganic Chemistry, University of Heidelberg, Heidelberg, Germany \\ Correspondence to: T. Krause (torsten.krause@geow.uni-heidelberg.de)
}

Received: 18 September 2013 - Published in Biogeosciences Discuss.: 5 November 2013

Revised: 28 February 2014 - Accepted: 6 April 2014 - Published: 28 May 2014

\begin{abstract}
Volatile organic compounds like furan and its derivatives are important for atmospheric properties and reactions. In this work the known abiotic formation of furan from catechol under Fenton-like conditions with $\mathrm{Fe}^{3+}$ sulfate was revised by the use of a bispidine $\mathrm{Fe}^{2+}$ complex as a model compound for iron with well-known characteristics. While total yields were comparable to those with the $\mathrm{Fe}^{3+}$ salt, the bispidine $\mathrm{Fe}^{2+}$ complex is a better catalyst as the turnover numbers of the active iron species were higher. Additionally, the role of iron and $\mathrm{pH}$ is discussed in relation to furan formation from model compounds and in natural sediment and water samples collected from the Dead Sea and several salt lakes in Western Australia. Various alkylated furans and even traces of halogenated furans (3-chlorofuran and 3-bromofuran) were found in some Australian samples. 3 -chlorofuran was found in three sediments and four water samples, whereas 3-bromofuran was detected in three water samples. Further, the emission of furans is compared to the abundance of several possible precursors such as isoprene and aromatic hydrocarbons as well as to the related thiophenes.

It is deduced that the emissions of volatile organic compounds such as furans contribute to the formation of ultrafine particles in the vicinity of salt lakes and are important for the local climate.
\end{abstract}

\section{Introduction}

Furans are heterocyclic aromatic compounds with a fivemembered ring consisting of four carbons and one oxygen atom and are closely related to the sulfur-containing thio- phenes. With manifold natural and anthropogenic sources furans are an important class of volatile organic compounds (VOCs).

Furan and several mono- and dialkylated furans were found in forest soils by applying pyrolysis GC/MS (Hempfling and Schulten, 1990) and furfural as well as 2pentylfuran in soil samples containing plant litter (Leff and Fierer, 2008; Jordan et al., 1993). Plant material was confirmed as a source of furans by several studies including living plants (Isidorov et al., 1985), leaf litter (Isidorov and Jdanova, 2002) and solid woods (Risholm-Sundman et al., 1998).

Huber et al. (2010) showed that soils are also an abiotic source for furans and presented a formation pathway for producing furans from catechol and similar precursors using Fenton-like reaction conditions.

In this study the biomimetic nonheme bispidine $\mathrm{Fe}^{2+}$ complex $\left[\mathrm{Fe}^{\mathrm{II}}\left(\mathrm{N}_{2} \mathrm{Py}_{2}\right)(\mathrm{OTf})_{2}\right]$ (Fig. 1) was used as model compound for natural iron complexes to investigate abiotic furan formation under Fenton conditions. Bispidine complexes have a defined coordination sphere due to the rigid adamantane backbone (Comba et al., 2010) and are well studied in their coordination with catechol (Comba et al., 2011) as well as their redox reaction with hydrogen peroxide (Bukowski et al., 2006). Aside from that, such chelating agent can be used to enhance the reaction and to impede side reactions.

Further sources of furans are biomass burning (Christian et al., 2003) and food processing (Rogge et al., 1991). Atmospheric oxidation reactions of 1,3-butadiene and 1,3pentadiene yield furan and 2-methylfuran (Ohta, 1984), respectively, while isoprene, the most abundant volatile biogenic compound, is oxidised to 3-methylfuran (Atkinson 
<smiles>COC(=O)C12CN(C)CC3(C(=O)OC)C(=O)C3(CCN1C)[C@@H](c1ccccn1)N(C)C2c1ccccn1</smiles>

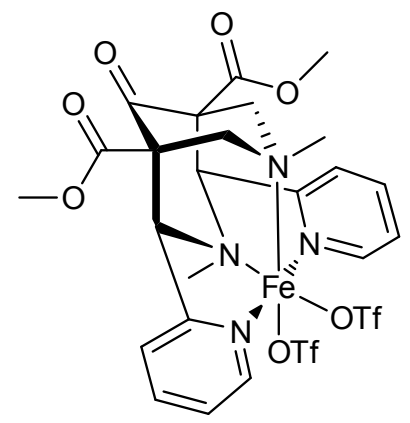

Figure 1. Structure of the bispidine $\mathrm{N}_{2} \mathrm{Py}_{2}$ ligand (left) and geometry of the $\left[\mathrm{Fe}^{\mathrm{II}}\left(\mathrm{N}_{2} \mathrm{Py}_{2}\right)(\mathrm{OTf})_{2}\right]$ complex (right).

et al., 1989). Moreover, anthropogenic benzene (Berndt and Boge, 2001), toluene (Dumdei et al., 1988) and xylenes (Shepson et al., 1984) are degraded to furans by $\mathrm{OH}$ radical reactions in the atmosphere.

According to the maximum incremental reactivity (MIR) scale furans play an important role in the formation of ground-level ozone (Carter, 2009). In addition, furans have an impact on the oxidative budget of the lower troposphere reacting with $\mathrm{NO}_{3}$ radicals at night-time (Kind et al., 1996; Berndt et al., 1997) and with OH radicals (Bierbach et al., 1995) or ozone (Atkinson et al., 1983) at daytime. The atmospheric lifetime of furan is about $4 \mathrm{~h}$ in the presence of $\mathrm{OH}$ radicals and decreases with higher alkylation (Bierbach et al., 1995; Gu et al., 1985). The reaction rate of 3-methylfuran with $\mathrm{OH}$ radicals is similar if not even higher than its precursor isoprene (Atkinson et al., 1989; Gu et al., 1985). Furthermore, furans react with $\mathrm{OH}$ radicals producing secondary organic aerosol (SOA) (Gómez Alvarez et al., 2009). Such newly formed particles at the nanometre scale are of significant importance in the troposphere altering cloud microphysics. They act as additional cloud condensation nuclei (Pierce and Adams, 2007), increasing the amount of new small droplets in clouds while reducing the size of old droplets leading to a change in the radiative properties and to rain suppression (Khain et al., 2005).

Another atmospheric sink for furans, mainly attributed to the marine boundary layer, is the reaction with $\mathrm{Cl}$ radicals being even faster compared to $\mathrm{OH}$ radicals (Villanueva et al., 2009; Cabañas et al., 2005) and possibly a source for halogen-induced organic aerosol (XOA; Ofner et al., 2013). Reactive chlorine species are also abundant in the vicinity of various salt lakes in arid and semi-arid environments (Stutz et al., 2002). These terrestrial sources for atmospheric chlorine and other reactive halogen species become even more important with the expansion of salt lakes and salt-influenced soils around the globe because of anthropogenic salinisation (Williams, 1999). For example, high atmospheric concentrations of reactive bromine oxide (Matveev et al., 2001) and iodine oxide (Zingler and Platt, 2005) were measured over the Dead Sea. Sediment and water samples from the Dead Sea are also part of the study in hand on the natural occurrence of furans. Additional sample locations were various salt lakes in the Western Australian wheat belt. These salt lakes are of peculiar interest because of their geochemical properties and their atmospheric impact. On the one hand, chemical parameters such as iron content and $\mathrm{pH}$ vary significantly between adjacent lakes (Bowen and Benison, 2009) and on the other hand, the formation of ultra-fine particles was measured in the vicinity of the salt lakes which are assumed to be responsible for decreasing rainfall in the area over the last decades (Junkermann et al., 2009).

Additionally, the investigated salt lakes are situated in regions favouring high seasonal temperatures and elevated solar radiation. The latter is important for a constant supply of $\mathrm{H}_{2} \mathrm{O}_{2}$ in surface waters and top soils (Cooper et al., 1988) which is essential in Fenton reactions including abiotic furan formation. $\mathrm{H}_{2} \mathrm{O}_{2}$ is also formed in the atmosphere and is transported to the surface by rain events, especially during thunderstorms (Deng and Zuo, 1999; Gunz and Hoffmann, 1990).

The natural occurrence of furans in salt lake sediments including the abiotic pathway provides the basis to understand the atmospheric impact of saline environments with regard to particle formation and local climate changes.

The first part of the paper concerns the abiotic furan formation using a bispidine $\mathrm{Fe}^{2+}$ complex in a Fenton reaction with catechol and the second part deals with the abundance and the underlying conditions of furan emissions from natural salt lake sediments and waters.

\section{Experimental section}

\subsection{Chemicals}

The following chemicals were used: catechol (99\%; Sigma-Aldrich), 4-ethylcatechol (95\%; Aldrich), hydrogen peroxide (30\%; Merck), [ $\left[\mathrm{Fe}^{\mathrm{II}}\left(\mathrm{N}_{2} \mathrm{Py}_{2}\right)(\mathrm{OTf})_{2}\right]$ (Börzel et al., 2002), $\mathrm{Fe}^{3+}$-sulfate (99\%; Fe 21-23\%; Riedel-de Haën), furan (99\%; Fluka), 2-methylfuran (99\%; Sigma-Aldrich), 2-ethylfuran (97\%; Aldrich), 2-propylfuran (97\%; abcr), 2-butylfuran (98\%; abcr), 2-pentylfuran (97\%; Aldrich), 2,3-dimethylfuran (99\%; Aldrich), 2,5-dimethylfuran (99\%; Aldrich), 3-chlorofuran (Zhang et al., 2005), 3-bromofuran (97\%, Aldrich), thiophene (99\%; Aldrich), 2 methylthiophene (98\%; Aldrich), 3-methylthiophene (99\%; Aldrich), Isoprene (99\%; Aldrich), EPA 624 calibration mix B (analytical standard; Supelco), sulfur mix (analytical standard; Spectrum Quality Standards), potassium chloride ( $99.5 \%$; Merck), sodium hydroxide ( $99 \%$; Aldrich), sulfuric acid (96\%; Riedel-de Haën), nitric acid (65\%; Bernd Kraft), calcium carbonate (99\%; LECO). Type I ultrapure water $\left(>=18 \mathrm{M} \Omega \mathrm{cm}^{-1}\right.$ ) from a Purelab UHQ System by ELGA LabWater was used in all experiments. 


\subsection{Sediment samples}

Forty-nine samples from Australia in 2011, 30 samples from Australia in 2012 and 13 samples from the Dead Sea, Israel, in 2012 were analysed for various chemical parameters and the natural abundance of furanoic compounds. Sampling locations were selected in the context of SOA formation events (Junkermann et al., 2009; Kamilli et al., 2013), reactive atmospheric halogen observations (Holla, 2013) and to cover a broad range of multifarious geochemical characteristics. The samples were taken from salt lakes or salt-influenced sediments from various depths and were stored cooled for transportation. The sediment samples were freeze dried for long-term storage and in order to remove residues of volatile compounds in a Lyovac GT2 by Steris. Afterwards, the samples were ground using a Pulverisette 5 planetary mill by Fritsch to a grain size below $315 \mu \mathrm{m}$ for homogenisation.

\subsection{Water samples}

The water samples consisted of eight samples from Australia in 2011, eight samples from Australia in 2012 and seven samples from the Dead Sea in 2012. For analysis, triplicates of $10 \mathrm{~mL}$ lake water were transferred into $20 \mathrm{~mL}$ headspace vials, closed with air-tight caps on site and stored at $4{ }^{\circ} \mathrm{C}$ until measurement. Additionally, water samples for iron analysis were sampled and stabilised by acidification.

\subsection{Instrumentation}

For the analysis of VOC (b.p. $-24^{\circ} \mathrm{C}$ to $200^{\circ} \mathrm{C}$ ) a Varian gas chromatograph GC 3400 linked to a Varian Saturn 4D with electron impact ionisation and ion trap mass spectrometer was used. The GC was equipped with a J\&W Scientific DB-5 (60 m; $0.32 \mathrm{~mm}$ i.d.; $1 \mu \mathrm{m}$ film thickness) capillary column by Agilent Technologies. Dynamic injection and preconcentration was performed by a customised purge and trap system (Mulder et al., 2013).

The total iron content of the sediment samples was measured by X-ray fluorescence using an energy-dispersive miniprobe multi-element analyser (EMMA) (Cheburkin et al., 1997) while dissolved iron of the water samples was quantified with an ICP-OES Vista MPX system by Varian. The $\mathrm{C}_{\text {org }}$ content of the sediments was calculated by subtraction of inorganic carbon content, analysed with a carbonate bomb (Müller and Gastner, 1971), from total carbon content analysed with a SC-144DR carbon/sulfur analyser by Leco. Dissolved organic carbon of the water samples from Australia was determined using a TOC-5000 by Shimadzu. The $\mathrm{pH}$ measurements were conducted with a Sentix 41 electrode from WTW calibrated on the free hydrogen scale with buffers by Merck at $\mathrm{pH} 4.01$ and 7.00.

\subsection{Experimental procedure}

Model reaction, natural sample and calibration measurements were conducted in $20 \mathrm{~mL}$ air-tight headspace glass vials with $10 \mathrm{~mL}$ aqueous phase and $10 \mathrm{~mL}$ gas phase. The septum of the headspace vials was punctuated by two stainless steel needles connected to a helium carrier gas reservoir and the GC/MS system, respectively. Before analysis the vials were shaken on a MTS 2 rotary board by IKA at $500 \mathrm{rpm}$ in the dark at a controlled temperature in a B10 incubator by Memmert for a defined time. Preceding GC, the analytes from the headspace vials were focused and preconcentrated on a glass lined tubing at $-190^{\circ} \mathrm{C}$. The purge flow of the helium carrier gas was $7 \mathrm{~mL} \mathrm{~min}^{-1}$ during the optimisation steps of the model reactions and $15 \mathrm{~mL} \mathrm{~min}^{-1}$ during the analysis of natural samples. After $7.5 \mathrm{~min}$ the analytes were transferred from the purge and trap system by helium (15 psi precolumn pressure) onto the GC column. The oven programme during the measurements of furan formation in model reactions was: $35^{\circ} \mathrm{C}$ held $8.30 \mathrm{~min}, 35^{\circ} \mathrm{C}$ to $150{ }^{\circ} \mathrm{C}$ at $5.5^{\circ} \mathrm{C} \mathrm{min}{ }^{-1}, 150^{\circ} \mathrm{C}$ held $5 \min , 150^{\circ} \mathrm{C}$ to $210^{\circ} \mathrm{C}$ at $30^{\circ} \mathrm{C} \mathrm{min}^{-1}, 210^{\circ} \mathrm{C}$ held $15 \mathrm{~min}$. For the natural samples and the Fenton-like reaction with 4-ethylcatechol the GC programme was modified: $30^{\circ} \mathrm{C}$ held $15.5 \mathrm{~min}, 30^{\circ} \mathrm{C}$ to $114^{\circ} \mathrm{C}$ at $5^{\circ} \mathrm{C} \mathrm{min}^{-1}, 114^{\circ} \mathrm{C}$ to $210^{\circ} \mathrm{C}$ at $30^{\circ} \mathrm{C} \mathrm{min}^{-1}$, $210^{\circ} \mathrm{C}$ held $8 \mathrm{~min}$. All GC/MS measurements were done at least in triplicate. Blanks were run at the beginning and the end of daily experimental series.

\subsubsection{Model reactions}

As in previous studies, catechol, being a model compound for natural organic matter, was used in the following oxidation reactions with iron and hydrogen peroxide to comprehend abiotic furan formation processes. In all experiments the catechol concentration amounted to $5 \mu \mathrm{mol}$ in a $10 \mathrm{~mL}(0.5 \mathrm{mM})$ aqueous phase while the concentration of iron, $\mathrm{H}_{2} \mathrm{O}_{2}, \mathrm{KCl}$ as well as reaction time, $\mathrm{pH}$ value and temperature were changed to yield an optimal furan formation.

\subsubsection{Optimisation of $\left[\mathrm{Fe}^{\mathrm{II}}\left(\mathrm{N}_{2} \mathrm{Py}_{2}\right)(\mathrm{OTf})_{2}\right]$}

To determine the optimal iron concentration for furan formation, $10 \mathrm{~mL}$ aqueous solutions containing $0.5 \mathrm{mM}$ catechol, $1 \mathrm{mM} \mathrm{H}_{2} \mathrm{O}_{2}$ and $5 \mathrm{mM} \mathrm{KCl}$ were assayed with 0 to $0.1 \mathrm{mM}$ bispidine $\mathrm{Fe}^{2+}$ complex. The solution had a pH of around 4.6 and was incubated for $30 \mathrm{~min}$ at $40^{\circ} \mathrm{C}$.

\subsubsection{Optimisation of hydrogen peroxide}

Optimal $\mathrm{H}_{2} \mathrm{O}_{2}$ concentration for the reaction was evaluated between 0 and $8 \mathrm{mM}$ while the other parameters were fixed at $12.5 \mu \mathrm{M}\left[\mathrm{Fe}^{\mathrm{II}}\left(\mathrm{N}_{2} \mathrm{Py}_{2}\right)(\mathrm{OTf})_{2}\right], 5 \mathrm{mM} \mathrm{KCl}, \mathrm{pH}$ of 4.6 and 30 min incubation time at $40^{\circ} \mathrm{C}$. 


\subsubsection{Time dependence}

With the optimal concentrations for $\mathrm{Fe}^{2+}$ at $12.5 \mu \mathrm{M}$ and $\mathrm{H}_{2} \mathrm{O}_{2}$ at $2 \mathrm{mM}$ and the initial settings of the solution $\mathrm{pH}$ of 4.6 as well as the incubation temperature of $40^{\circ} \mathrm{C}$ the reaction time was tried in turn between 0 and $24 \mathrm{~h}$ with $5 \mathrm{mM}$ $\mathrm{KCl}$.

\subsubsection{Optimisation of $\mathrm{pH}$}

The $\mathrm{pH}$ was adjusted with sulfuric acid or sodium hydroxide. The optimal reaction conditions were evaluated between a $\mathrm{pH}$ of 2.1 and 8.7 with concentration of $12.5 \mu \mathrm{M}$ $\left[\mathrm{Fe}^{\mathrm{II}}\left(\mathrm{N}_{2} \mathrm{Py}_{2}\right)(\mathrm{OTf})_{2}\right], 2 \mathrm{mM} \mathrm{H} \mathrm{H}_{2}$ and $5 \mathrm{mM} \mathrm{KCl}$. Incubation was accomplished at $40^{\circ} \mathrm{C}$ for $30 \mathrm{~min}$.

\subsubsection{Temperature dependence}

The temperature was changed between 20 and $70^{\circ} \mathrm{C}$ while the other parameters were held at $12.5 \mu \mathrm{M}$ $\left[\mathrm{Fe}^{\mathrm{II}}\left(\mathrm{N}_{2} \mathrm{Py}_{2}\right)(\mathrm{OTf})_{2}\right], 2 \mathrm{mM} \mathrm{H}_{2} \mathrm{O}_{2}$ and $5 \mathrm{mM} \mathrm{KCl}$, a solution $\mathrm{pH}$ of 4.6 and an incubation time of $30 \mathrm{~min}$. The furan calibration was adjusted to the varying temperatures to account for the change in furan vapour pressures.

\subsubsection{Optimisation of chloride}

With optimal concentrations of $12.5 \mu \mathrm{M}$ $\left[\mathrm{Fe}^{\mathrm{II}}\left(\mathrm{N}_{2} \mathrm{Py}_{2}\right)(\mathrm{OTf})_{2}\right], 2 \mathrm{mM} \quad \mathrm{H}_{2} \mathrm{O}_{2}$, a solution $\mathrm{pH}$ of 4.6 and an incubation time of $30 \mathrm{~min}$ at $40^{\circ} \mathrm{C}$ the $\mathrm{KCl}$ concentration was varied between 0 and $50 \mathrm{mM}$.

\subsubsection{Reaction with 4-ethylcatechol}

Furan formation with longer alkyl chains was tested under Fenton-like conditions using $50 \mu \mathrm{M} \mathrm{Fe}^{3+}$ sulfate with $0.35 \mathrm{mM} \mathrm{H}_{2} \mathrm{O}_{2}$ and $0.5 \mathrm{mM}$ 4-ethylcatechol as the precursor.

\subsubsection{Sediment samples}

$1 \mathrm{~g}$ milled sediment was suspended with $10 \mathrm{~mL}$ of water in a headspace vial and incubated at $40{ }^{\circ} \mathrm{C}$ for $24 \mathrm{~h}$ in the dark on the rotary board prior to measurements with GC/MS.

\subsubsection{Water samples}

The on-site sampled and at $4{ }^{\circ} \mathrm{C}$ stored $10 \mathrm{~mL}$ lake waters were incubated in their respective headspace vials for $1 \mathrm{~h}$ at $40^{\circ} \mathrm{C}$ in the dark on the rotary board.

\subsection{Identification and quantification}

The analytes were identified by comparison of the mass spectra with the National Institute of Technology MS library and with those obtained from commercial standards including their retention times. External multipoint calibrations were performed for all commercially available analytes and the synthesised 3-chlorofuran. In the case of 3-methylfuran and 2,4-dimethylfuran recovery rates analogous to their isomers were assumed. Additionally, the known ionisation energies of 3-methylfuran and 2-methylfuran are comparable with $8.64 \mathrm{eV}$ and $8.56 \mathrm{eV}$, respectively (Spilker and Grutzmacher, 1986).

\section{Results and discussion}

In the following the results of the model reactions and from the natural samples are presented and discussed. Geographical locations, geochemical properties and emission data from the natural samples listed in tabular form can be found in the Supplement.

\subsection{Model reactions}

In the course of the optimisation steps on furan formation from catechol an optimal $\left[\mathrm{Fe}^{\mathrm{II}}\left(\mathrm{N}_{2} \mathrm{Py}_{2}\right)(\mathrm{OTf})_{2}\right]$ concentration of $12.5 \mu \mathrm{M}$ was determined (Fig. 2a). In the absence of iron no detectable amount of furan was formed expressing the significance of iron in this reaction. Higher concentration led to a moderate depletion of furan concentrations levelling off in a steady plateau.

The optimal $\left[\mathrm{Fe}^{\mathrm{II}}\left(\mathrm{N}_{2} \mathrm{Py}_{2}\right)(\mathrm{OTf})_{2}\right]$ concentration equates to a molar ratio of $1: 40$ compared to $0.5 \mathrm{mM}$ catechol deployed in the experiments. In previous studies with $\mathrm{Fe}^{3+}$ sulfate by Huber et al. (2010) the optimal molar ratio of iron to catechol was $1: 5$. Hence, the turnover numbers are eight times higher than for the applied bispidine $\mathrm{Fe}^{2+}$ complex. This demonstrates not only the feasibility of the $\mathrm{Fe}^{2+}$ complex but also its superiority over $\mathrm{Fe}^{3+}$ sulfate. While the bispidine $\mathrm{Fe}^{2+}$ complex is stabilised in solution by its ligands, the $\mathrm{Fe}^{3+}$ salt is susceptible to precipitation and is removed from the reaction cycle. This cycle includes the oxidation of $\mathrm{Fe}^{2+}$ by $\mathrm{H}_{2} \mathrm{O}_{2}$ in the Fenton reaction to $\mathrm{Fe}^{3+}$ (Remucal and Sedlak, 2011) and forming a highly reactive $\mathrm{OH}$ radical and a hydroxyl anion (Haber and Weiss, 1932). $\mathrm{Fe}^{3+}$ on the other hand can be either reduced by catechol, which is a one to two electron donor, or by the Fenton-like reaction with $\mathrm{H}_{2} \mathrm{O}_{2}$ yielding in both cases $\mathrm{Fe}^{2+}$. In the former redox reaction catechol is either oxidised to 1,2-semiquinone in a oneelectron transfer or to 1,2-benzoquinone in a two-electron transfer. Additionally, the Fenton-like reaction yields a superoxide radical and a proton.

Following the iron optimisation step, $\mathrm{H}_{2} \mathrm{O}_{2}$ was the next important factor in this reaction. Again, as in the case of iron, the abundance of $\mathrm{H}_{2} \mathrm{O}_{2}$ is essential for the furan formation in this reaction. At high concentrations the furan yield declined, probably due to the promotion of side- and followup reactions leading to higher oxidised products (Studenroth et al., 2013). The optimal concentration was determined at $2 \mathrm{mM}$ (Fig. 2b) compared to $0.5 \mathrm{mM}$ catechol giving a mo- 
A

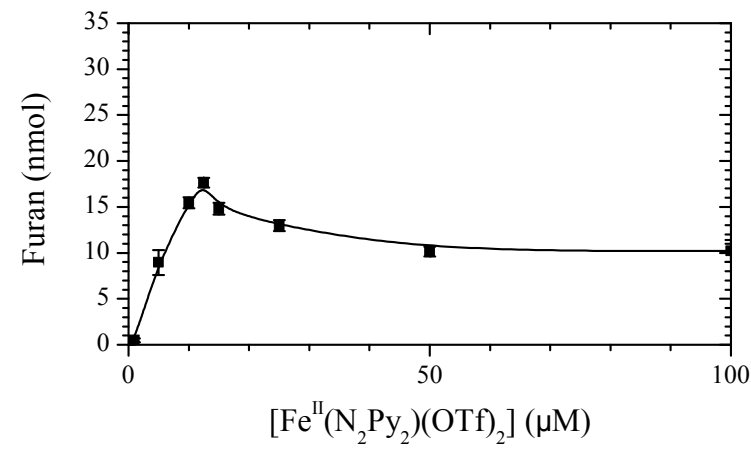

C

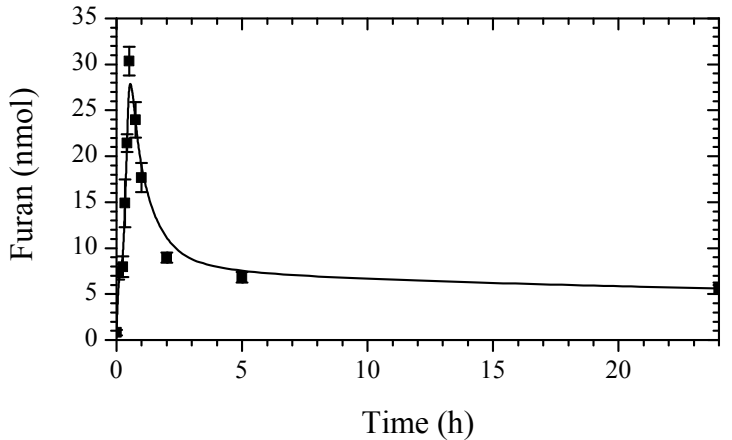

$\mathbf{E}$

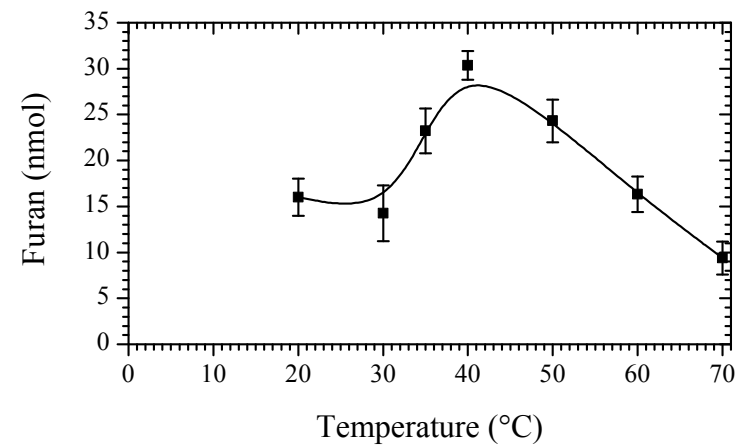

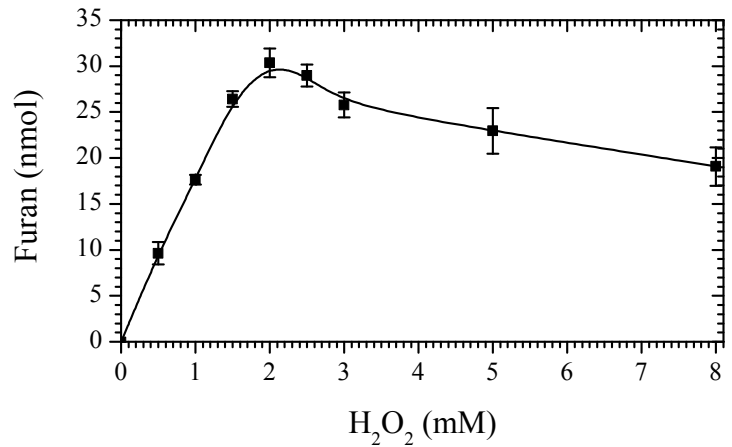

D

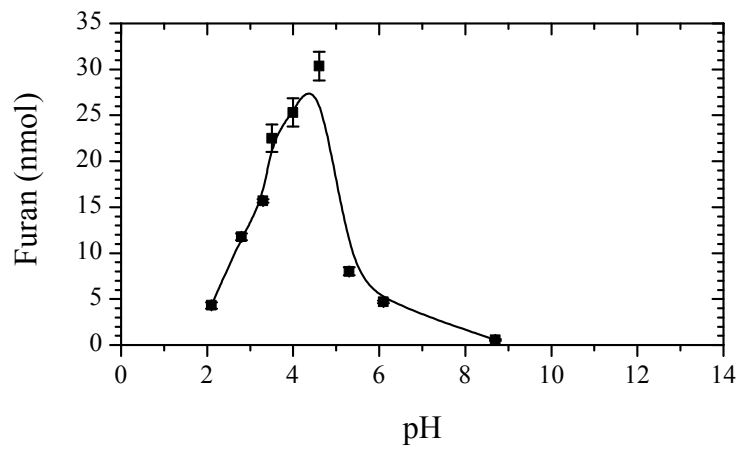

$\mathbf{F}$

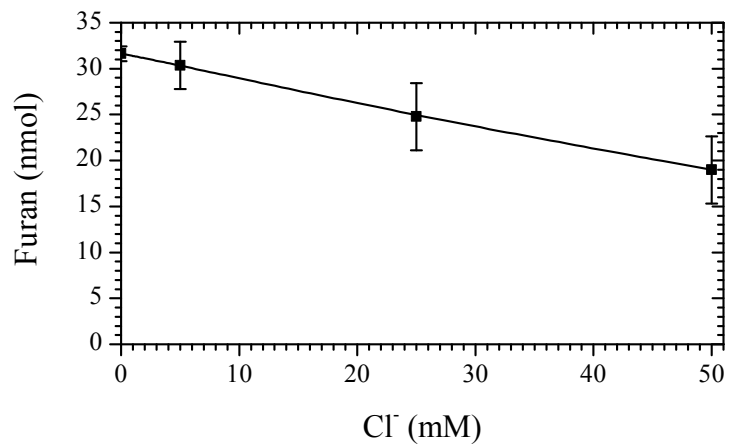

Figure 2. Effects of different parameters on the furan formation from a $10 \mathrm{~mL}$ solution. (A) Variation of $\left[\mathrm{Fe}^{\mathrm{II}}\left(\mathrm{N}_{2} \mathrm{Py}_{2}\right)(\mathrm{OTf})_{2}\right]$ : reaction of $0.5 \mathrm{mM}$ catechol with $0-100 \mu \mathrm{M}\left[\mathrm{Fe}^{\mathrm{II}}\left(\mathrm{N}_{2} \mathrm{Py}_{2}\right)(\mathrm{OTf})_{2}\right], 1 \mathrm{mM} \mathrm{H}_{2} \mathrm{O}_{2}, 5 \mathrm{mM} \mathrm{KCl}$ at a pH of 4.6 and $40^{\circ} \mathrm{C}$ after $30 \mathrm{~min}$. (B) Variation of $\mathrm{H}_{2} \mathrm{O}_{2}$ : reaction of $0.5 \mathrm{mM}$ catechol with $12.5 \mu \mathrm{M}\left[\mathrm{Fe}^{\mathrm{II}}\left(\mathrm{N}_{2} \mathrm{Py}_{2}\right)(\mathrm{OTf})_{2}\right], 0-8 \mathrm{mM} \mathrm{H}_{2} \mathrm{O}_{2}, 5 \mathrm{mM} \mathrm{KCl}$ at a pH of 4.6 and $40^{\circ} \mathrm{C}$ after $30 \mathrm{~min}$. (C) Time dependency: reaction of $0.5 \mathrm{mM}$ catechol with $12.5 \mu \mathrm{M}\left[\mathrm{Fe}^{\mathrm{II}}\left(\mathrm{N}_{2} \mathrm{Py}_{2}\right)(\mathrm{OTf})_{2}\right], 2 \mathrm{mM} \mathrm{H}_{2} \mathrm{O}_{2}, 5 \mathrm{mM} \mathrm{KCl}$ at a pH of 4.6 and $40^{\circ} \mathrm{C}$ after $0-24 \mathrm{~h}$. (D) Variation of $\mathrm{pH}$ : reaction of $0.5 \mathrm{mM}$ catechol with $12.5 \mu \mathrm{M}\left[\mathrm{Fe}^{\mathrm{II}}\left(\mathrm{N}_{2} \mathrm{Py}_{2}\right)(\mathrm{OTf})_{2}\right], 2 \mathrm{mM} \mathrm{H}_{2} \mathrm{O}_{2}, 5 \mathrm{mM} \mathrm{KCl}$ at a pH of $2.1-8.7$ and $40^{\circ} \mathrm{C}$ after $30 \mathrm{~min}$. (E) Temperature dependency: reaction of $0.5 \mathrm{mM}$ catechol with $\left.12.5 \mu \mathrm{M}\left[\mathrm{Fe}^{\mathrm{II}}\left(\mathrm{N}_{2} \mathrm{Py}\right)_{2}\right)(\mathrm{OTf})_{2}\right], 2 \mathrm{mM} \mathrm{H}_{2} \mathrm{O}_{2}, 5 \mathrm{mM} \mathrm{KCl}$ at a pH of 4.6 and $20-70{ }^{\circ} \mathrm{C}$ after $30 \mathrm{~min}$. (F) Variation of chloride: reaction of $0.5 \mathrm{mM}$ catechol with $12.5 \mu \mathrm{M}\left[\mathrm{Fe}^{\mathrm{II}}\left(\mathrm{N}_{2} \mathrm{Py}_{2}\right)(\mathrm{OTf})_{2}\right], 2 \mathrm{mM} \mathrm{H}_{2} \mathrm{O}_{2}$, $0-50 \mathrm{mM} \mathrm{KCl}$ at a pH of 4.6 and $40^{\circ} \mathrm{C}$ after $30 \mathrm{~min}$. Data points represent mean values with error bars indicating standard deviations from triplicate measurements.

lar ratio of $4: 1$ while in the previous study with $\mathrm{Fe}^{3+}$ sulfate the molar ratio was at $1: 1.4$ (Huber et al., 2010).

Reaction time under these conditions with a prominent optimal furan yield was $30 \mathrm{~min}$ (Fig. 2c). Afterwards a decline can be accounted for by an equilibrium of furan between the gas and aqueous phase. In the latter, furan can further react with hydroxyl radicals comparable to reactions in the gas phase (Gómez Alvarez et al., 2009; Atkinson et al., 1983).

The reaction was susceptible to $\mathrm{pH}$ variations of the solution with an optimum at 4.6 (Fig. 2d). At lower $\mathrm{pH}$ the reaction of $\left[\mathrm{Fe}^{\mathrm{II}}\left(\mathrm{N}_{2} \mathrm{Py}_{2}\right)(\mathrm{OTf})_{2}\right]$ and $\mathrm{H}_{2} \mathrm{O}_{2}$ is inhibited due to slower reaction rates between iron and hydrogen peroxide while at higher $\mathrm{pH}$ iron precipitation takes place and $\mathrm{OH}$ radical formation is inhibited (Remucal and Sedlak, 2011).

The initial temperature of $40^{\circ} \mathrm{C}$ for the experiments was also the optimal temperature (Fig. 2e). Lower temperatures are accompanied by lower energy input to the reaction while higher temperatures again could promote side and follow-up reactions.

While chloride had seemingly no influence on the reaction of $\mathrm{Fe}^{3+}$ sulfate with $\mathrm{H}_{2} \mathrm{O}_{2}$ and catechol (Huber et al., 2010), the reaction with the bispidine $\mathrm{Fe}^{2+}$ complex is inhib- 


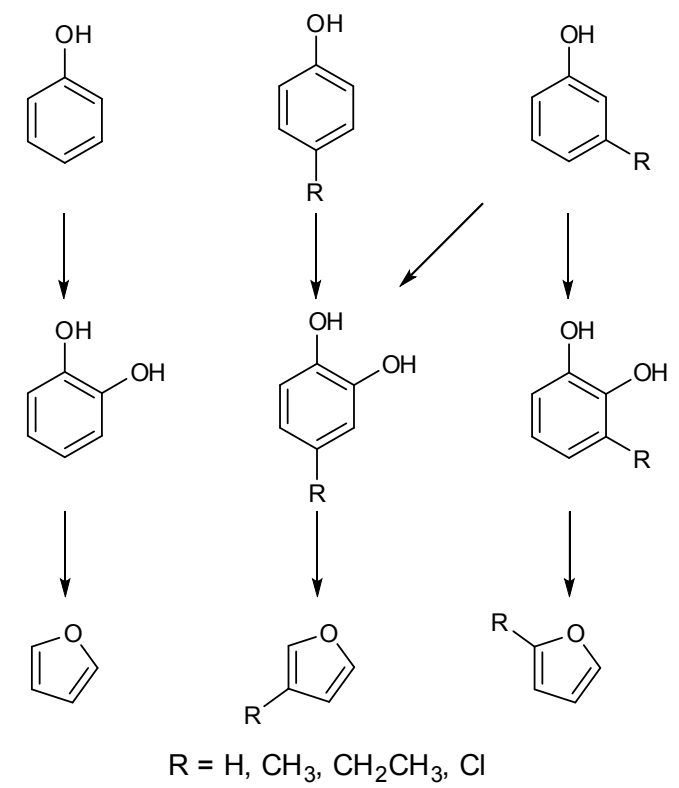

Figure 3. Degradation pathways of phenol and catechol derivatives to furanoic species (Huber et al., 2010) including ethyl moieties.

ited (Fig. 2f) due to the radical scavenger traits of chloride (Grebel et al., 2010). Furan yields decreased linearly with increasing amounts of chloride. Highest furan yields were attained in the absence of chloride.

Overall, the bispidine $\mathrm{Fe}^{2+}$ complex is a feasible model compound with furan yields of $31.6 \mathrm{nmol}(2.15 \mu \mathrm{g})$ from $5 \mu \mathrm{mol}$ catechol under optimal conditions. This accounts for a turnover rate of $0.6 \%$ from catechol and is comparable with the overall yield of the previous study using $\mathrm{Fe}^{3+}$ sulfate (Huber et al., 2010). The main products of catechol degradation by Fenton chemistry are dicarboxylic acids and carbon dioxide (M'Hemdi et al., 2012; Studenroth et al., 2013).

In the former studies only methylated catechols or phenols were used in Fenton-like reactions leading to mono- or dimethylated furans depending on the educts (Huber et al., 2010). Due to the fact that furans with extended alkyl chains were found in natural environments the Fenton-like reaction was extended to 4-ethylcatechol as a commercially available and soluble catechol derivative. In the Fenton-like reaction of $\mathrm{Fe}^{3+}$ sulfate with 4-ethylcatechol the presumed 3-ethylfuran was obtained. Fig. 3 depicts the postulated degradation pathways from phenols and catechols to furanoic compounds (Huber et al., 2010) expanded to include ethyl moieties.

\subsection{Sediment samples}

The model reactions were accompanied by a survey spanning over two years in which 92 sediment samples from different salt lakes in Western Australia and of the Dead Sea in Israel were collected and analysed for the emission of furanoic compounds. Additionally, the emission data were correlated to iron concentration and organic carbon content, as well as $\mathrm{pH}$ to compare the results from these natural samples with the model reactions. $\mathrm{Fe}^{2+}$ as used in these investigations was abundant in the Australian samples identified by the chelating agent 2,2'-bipyridine. Besides black sediment layers containing pyrite the wet sediments, ground and surface waters contained soluble $\mathrm{Fe}^{2+}$ (Shand et al., 2008; Degens and Shand, 2010). On the one hand, total iron content ranged from 0.46 to $3.6 \mathrm{w} \%$, organic carbon from below $0.1 \mathrm{w} \%$ up to $5.9 \mathrm{w} \%$ and $\mathrm{pH}$ from 4.2 to 8.4 for the Australian samples displaying a wide divergence, while for the Dead Sea samples on the other hand, total iron content was between 1.2 to $1.8 \mathrm{w} \%$, organic carbon concentration was below $0.1 \mathrm{w} \%$ up to $0.56 \mathrm{w} \%$ and $\mathrm{pH}$ was between 7.7 and 8.1 (Fig. 4a).

As expected from a previous work by Huber et al. (2010), furan as well as 2-methylfuran and 3-methylfuran were emitted from most sediment samples. Additionally, 2,3-2,4- and 2,5-dimethylfuran, 2-ethylfuran, 2-propylfuran, 2-butylfuran and 2-pentylfuran were identified from various sediments. Most of these compounds are known to be products from food processing, plants and woods but are rarely mentioned in connection with soils and sediments. Furan and the two methylfuran isomers are the most prominent furan species in the samples followed by further monoalkylated furans, while the concentrations of dimethylated furans were significantly lower (Fig. 4b).

Of all the above-mentioned furanoic compounds, furan shows the most significant dependency to iron and organic carbon content (Fig. 5a and c). Hence, emissions tend to be higher with elevated iron and carbon concentrations. Less obvious is a correlation with $\mathrm{pH}$ (Fig. 5b), though a statistical increase under acidic conditions is indicated by the linear regression fitted through the data points. These findings agree with the model reactions where iron is needed in the redox reactions under slightly acidic conditions.

The concentrations of alkylated furans tend to increase with the organic carbon content but seem to be rather independent of $\mathrm{pH}$ or iron concentration.

For an acidic Lake Boats sediment sample $(0-2 \mathrm{~cm})$ a time dependency for the emission of VOCs was established between 1 and $96 \mathrm{~h}$ incubation time (Fig. 6a). An exponential increase of the furan concentration over time is shown revealing that the formation of compounds with low boiling points takes place during incubation rather than being remnants in the samples after freeze drying. This sample was selected because of its low $\mathrm{pH}$ and the release of various halogenated products.

Similar to catechol further aromatic compounds like phenols and other aromatic hydrocarbons react with hydroxyl radicals forming furans. From atmospheric research it is known that toluene is a precursor for 2-methylfuran (Shepson et al., 1984) and benzene for furan (Berndt and Boge, 2001), respectively. It can be assumed that ethyl benzene is a precursor for 2-ethylfuran. In aqueous phase chemistry aromatic hydrocarbons like benzene are oxidised by hydroxyl 

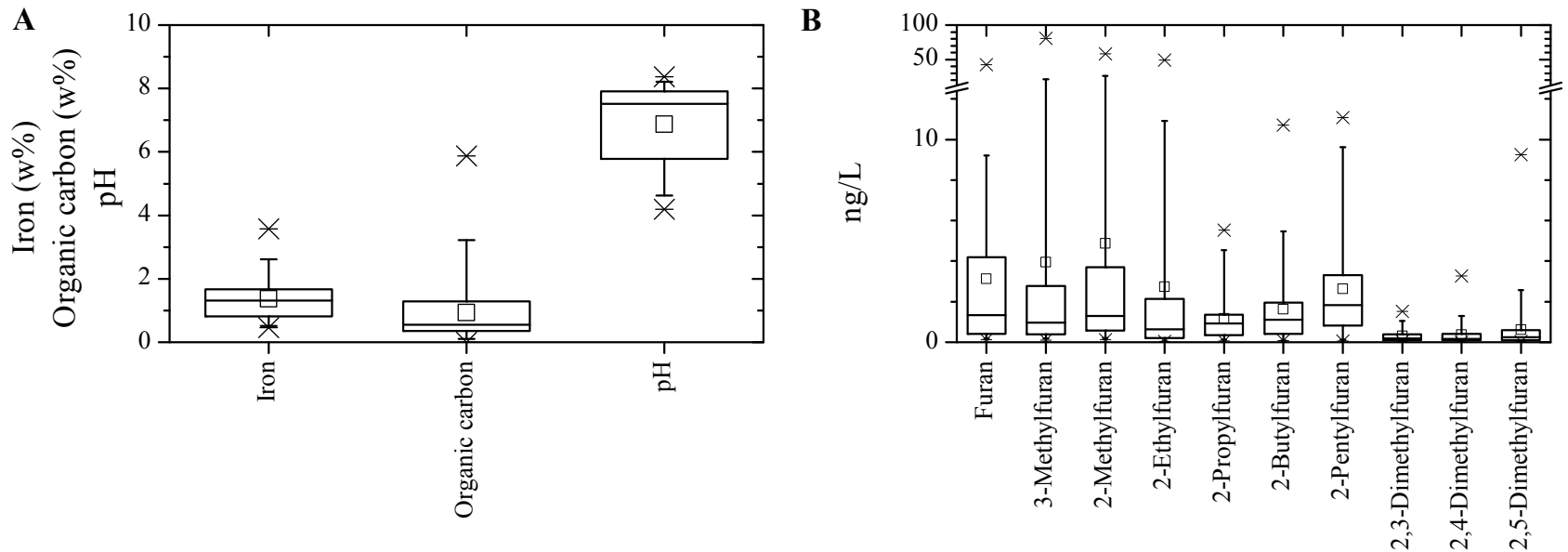

Figure 4. Distribution of (A) iron and organic carbon concentration as well as $\mathrm{pH}$ and (B) of the furan emissions from the various Australian and Dead Sea sediment samples.
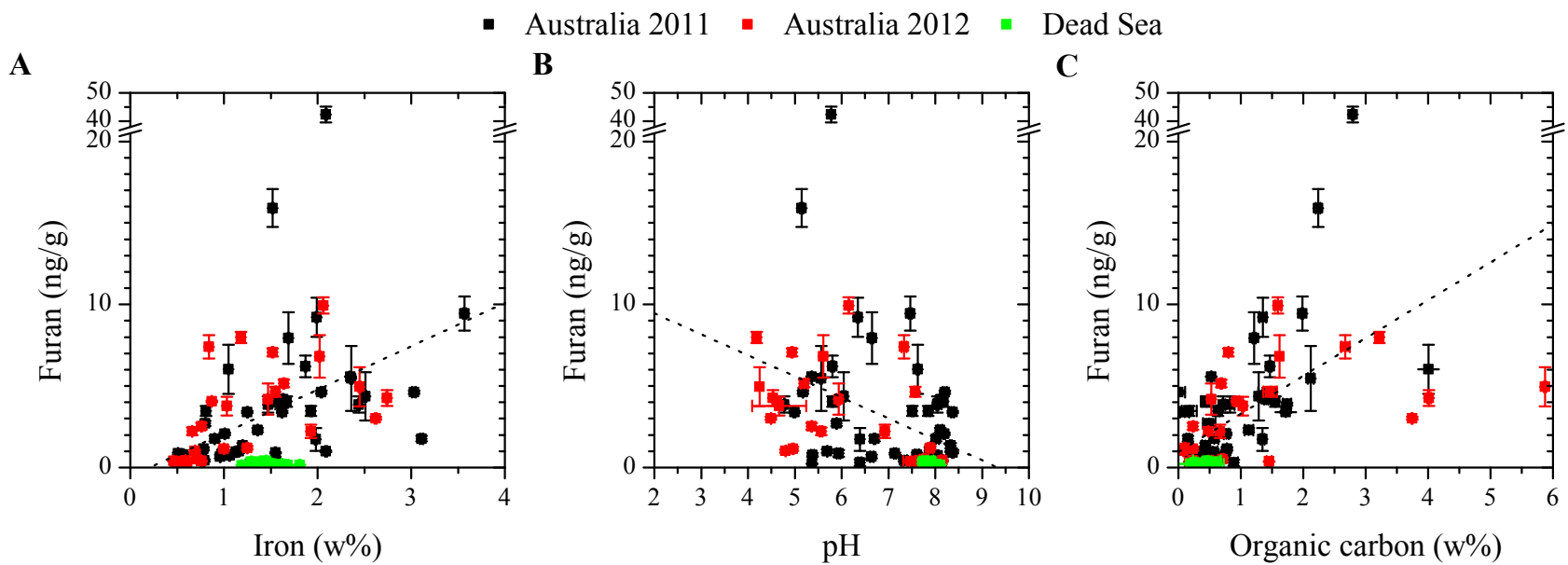

Figure 5. Furan emissions dependent on (A) iron concentration, (B) pH and (C) organic carbon content of the sediments (Australia 2011: black; Australia 2012: red; Dead Sea 2012: blue). Data points represent mean values with error bars indicating standard deviations from triplicate measurements.

radicals to phenols and catechols (Zhang et al., 1995), which are further degraded to furans as demonstrated by model reactions with the bispidine $\mathrm{Fe}^{2+}$ complex or $\mathrm{Fe}^{3+}$ sulfate (Huber et al., 2010). From data plots a correlation between benzene concentrations and furan emissions can be deduced (Fig. 6c). However, a coherence between toluene abundance and 2-methylfuran emission is ambiguous (Fig. 6d) and there is no correlation between ethylbenzene and 2-ethylfuran (Fig. 6e).

The oxidation of isoprene with hydroxyl radicals in the gas phase yields small amounts of 3-methylfuran (Atkinson et al., 1989). While isoprene was detected in the headspace with concentrations up to $111 \mathrm{ng} \mathrm{g}^{-1}$ the data plot shows no obvious relation between isoprene and 3-methylfuran (Fig. 6f). Additionally, the concentrations of 3-methylfuran and 2-methylfuran after incubation display a linear connection demonstrating a possible mutual origin (Fig. 6b).

Furthermore, the emissions of other heterocyclic aromatics such as thiophene, 2- and 3-methylthiophene plotted against the respective furans show a linear dependency between these compounds (Fig. 7a-c). Hence, this suggests a mutual precursor and a competition between thiol and hydroxyl groups during the reaction.

Additionally, several furans not mentioned before in the study of Huber et al. (2010) were found in the Australian and Dead Sea samples, including a series of alkylated furans from ethylfuran to pentylfuran. While the 2-alkylfuran isomers were abundant, the 3-alkylfuran isomers were found in none of the samples.

The finding of 3-chlorofuran (up to $0.37 \mathrm{ng} \mathrm{g}^{-1}$ ) in three of the Australian samples deserves special attention. 3- 
A

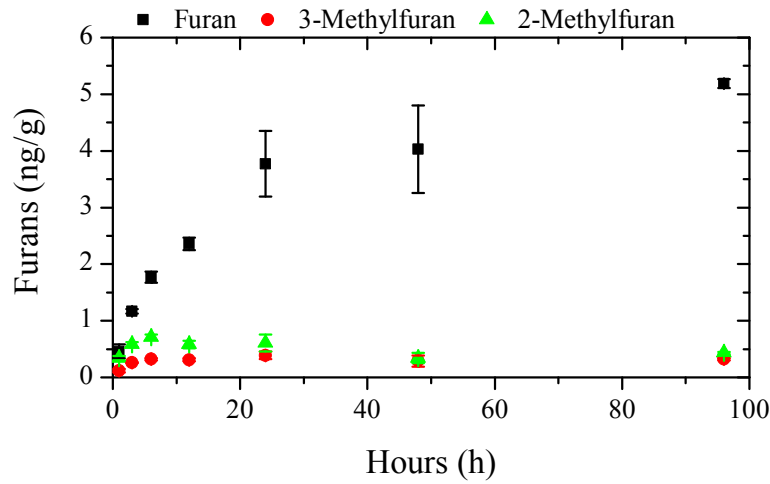

C

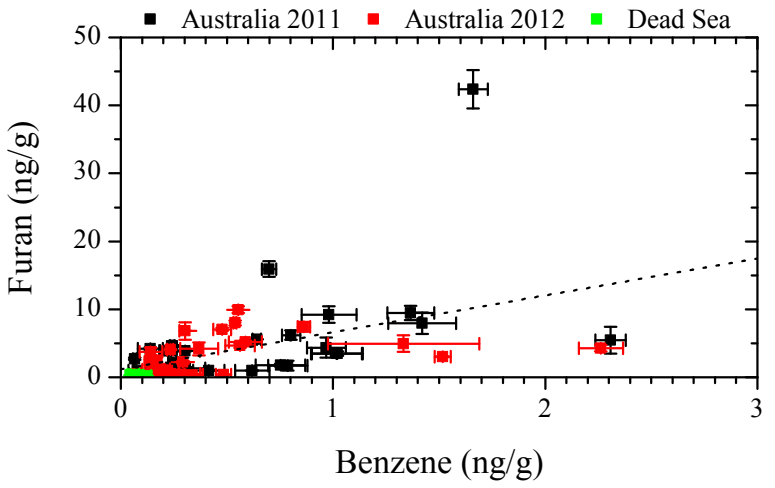

$\mathbf{E}$

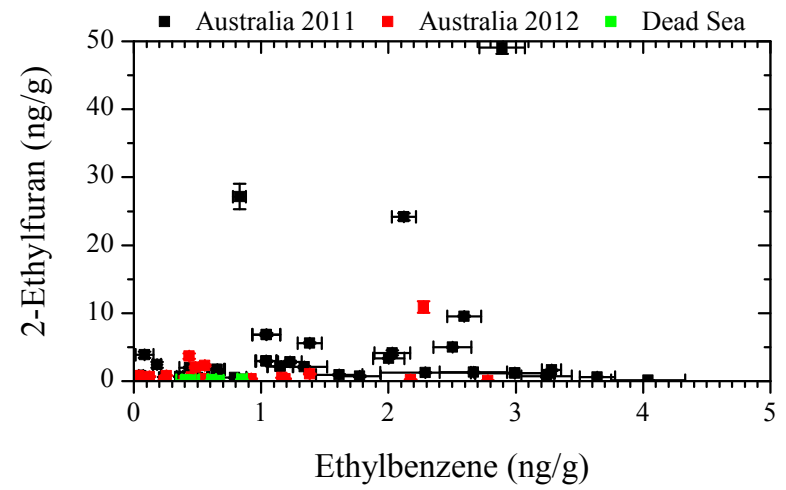

B

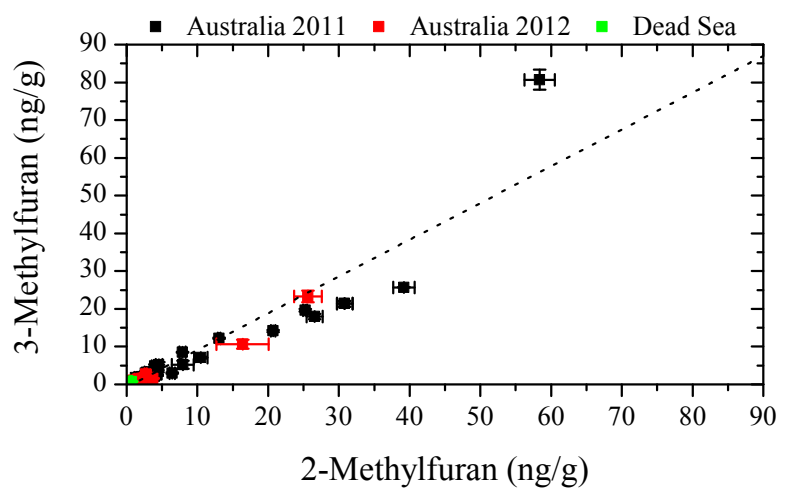

D

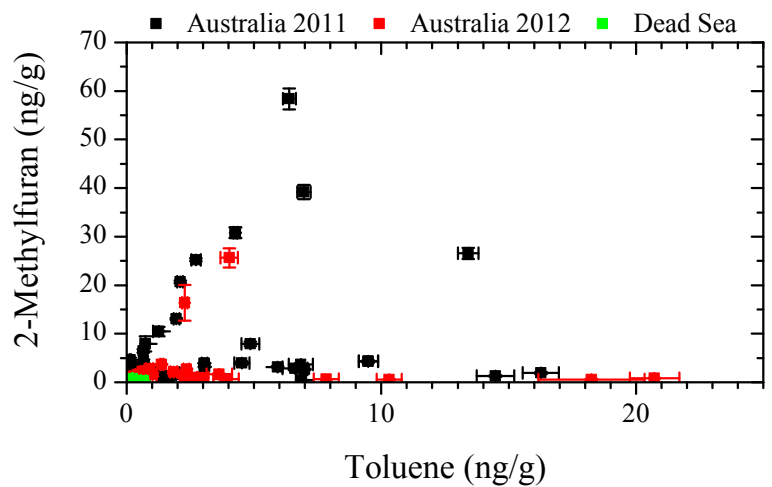

$\mathbf{F}$

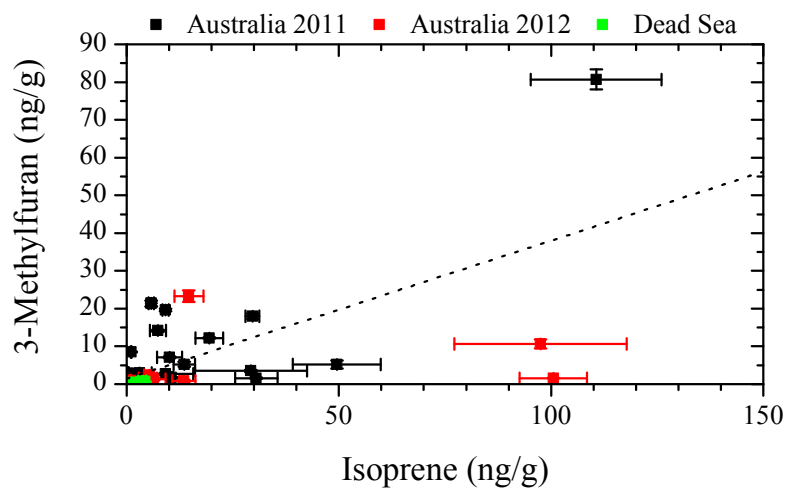

Figure 6. (A) Temporal distribution of the furan (black), 2-methylfuran (green) and 3-methylfuran (red) from Lake Boats sample (0-2 cm). Correlation between (B) 2-methylfuran and 3-methylfuran emissions, (C) furan and benzene, (D) 2-methylfuran and toluene, (E) 2-ethylfuran and ethylbenzene and (F) 3-methylfuran and isoprene from sediment samples (Australia 2011: black; Australia 2012: red; Dead Sea 2012: blue). Data points represent mean values with error bars indicating standard deviations from triplicate measurements.

chlorofuran was a compound found by Huber et al. (2010) during the reaction of $\mathrm{Fe}^{3+}$ with hydrogen peroxide and chlorinated catechols and phenols. Hypothetical atmospheric chlorination by chlorine atoms and sorption on the sediment matrix prior sampling are unlikely due to the unfavourable energy states of the formed intermediate (Zhang and Du, 2011). Hence, the source should be terrestrial in nature.

The Dead Sea samples show an overall lower emission compared to the Australian samples which is in good compliance with lower organic carbon and iron content as well as higher $\mathrm{pH}$.

Even though formation processes are more complex in sediments due to the nature of the matrix and to com- peting redox reactions than in model reactions, the furan formation shows a clear dependency on iron content and $\mathrm{pH}$ which were also important parameters in the model reactions with catechol.

\subsection{Water samples}

During the three campaigns 23 water samples were collected in air-tight vials on site. Dissolved iron content for the Australian samples ranged from below the detection limit $\left(0.2 \mathrm{mg} \mathrm{L}^{-1}\right)$ to $173 \mathrm{mg} \mathrm{L}^{-1}$ correlating with a $\mathrm{pH}$ between 8.7 and 2.4. In all of the Dead Sea samples the iron content 
- Australia 2011 - Australia 2012 - Dead Sea

A

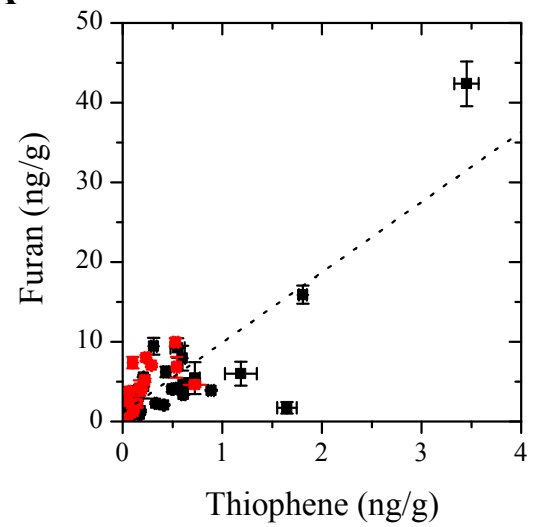

B

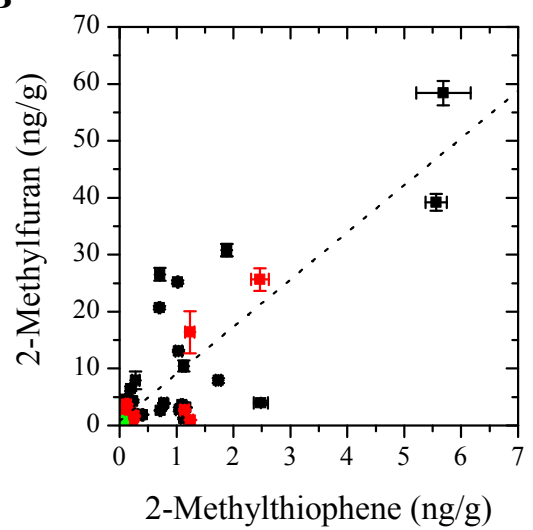

C

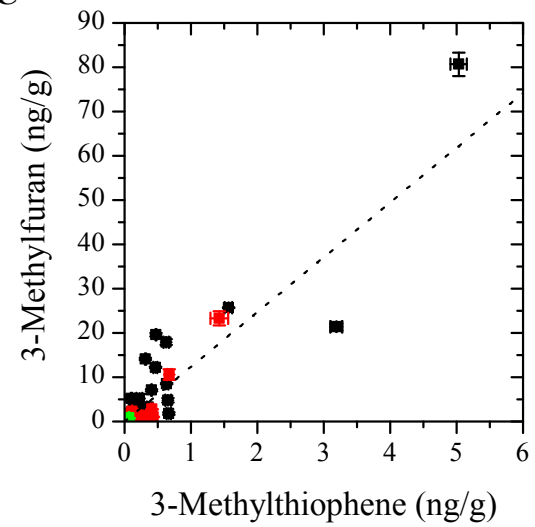

Figure 7. Correlation between the emission of related heterocyclic aromatic compounds such as (A) furan and thiophene, (B) 2-methylfuran and 2-methylthiophene and (C) 3-methylfuran and 3-methylthiophene from sediment samples (Australia 2011: black; Australia 2012: red; Dead Sea 2012: blue). Data points represent mean values with error bars indicating standard deviations from triplicate measurements.
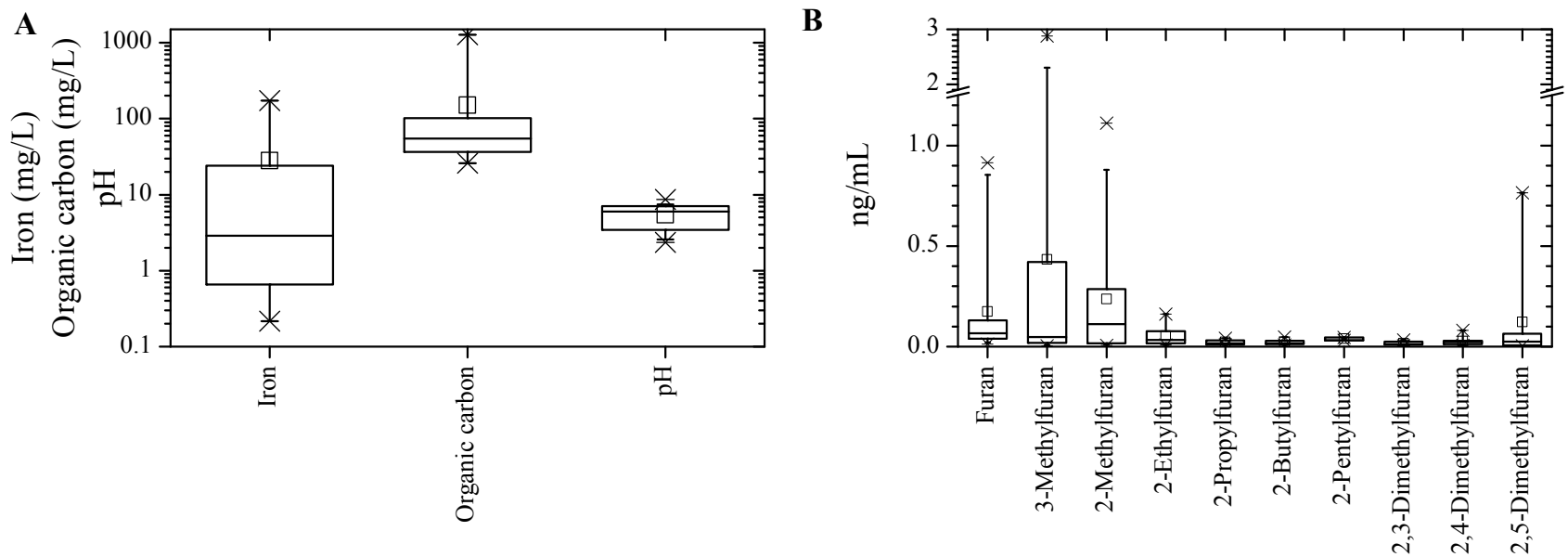

Figure 8. Distribution of (A) iron and organic carbon concentration as well as $\mathrm{pH}$ and (B) of the furan emissions from the various Australian and Dead Sea water samples. Only the Australian water samples were analysed for organic carbon.

was below the detection limit $\left(0.2 \mathrm{mg} \mathrm{L}^{-1}\right)$ while the $\mathrm{pH}$ was between 5.1 and 6.5 (Fig. 8a).

Water analysis showed the abundance of the different furan species that were also found in the sediment samples (Fig. 8b) including traces of 3-chlorofuran with concentrations up to $0.35 \mathrm{ng} \mathrm{mL}^{-1}$ in four samples. Additionally, the homologous 3-bromofuran was found in three samples with concentrations up to $0.03 \mathrm{ng} \mathrm{mL}^{-1}$. Until now this compound was only known to be a product of onion bulbs incubated with the Proteobacteria Erwinia carotovora now called Pectobacterium carotovorum (Prithiviraj et al., 2004).

Furan emission was less pronounced in relation to the methylated furans while higher alkylated furan concentrations were on par with the dimethylated furans. One reason for the discrimination of higher alkylated furans could be the short incubation time of one hour compared to $24 \mathrm{~h}$ for the sediments. The water samples confirm the natural abundance of furan and its derivatives in the studied salt lakes. Likewise, the emissions from sediments furan and 3-methylfuran concentrations are higher with elevated dissolved iron content and lower $\mathrm{pH}$ values (Fig. 9a-d). However, 2-methylfuran neither shows a correlation with iron content and $\mathrm{pH}$ value nor with the concentration of 3-methylfuran as was demonstrated for the sediments.

\section{Conclusions}

The previously established model reaction by Huber et al. (2010) for an abiotic furan formation from catechol was verified using a bispidine $\mathrm{Fe}^{2+}$ complex. Furthermore, the formation of ethyl furan from ethyl catechol was assayed and 
A

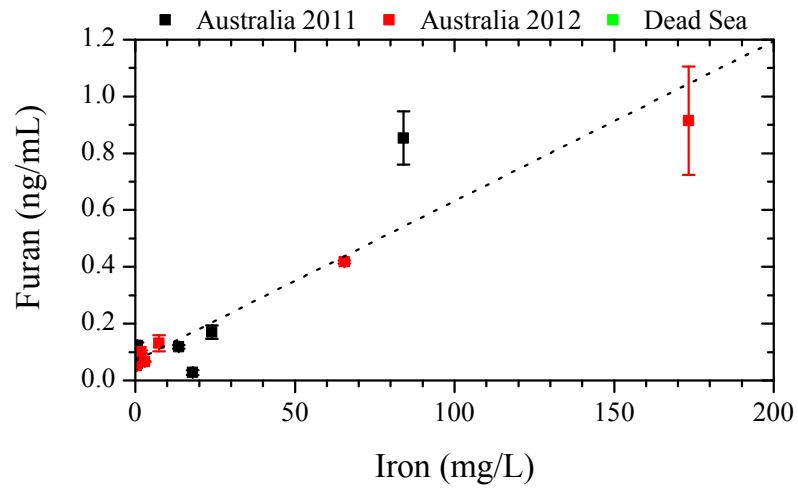

C

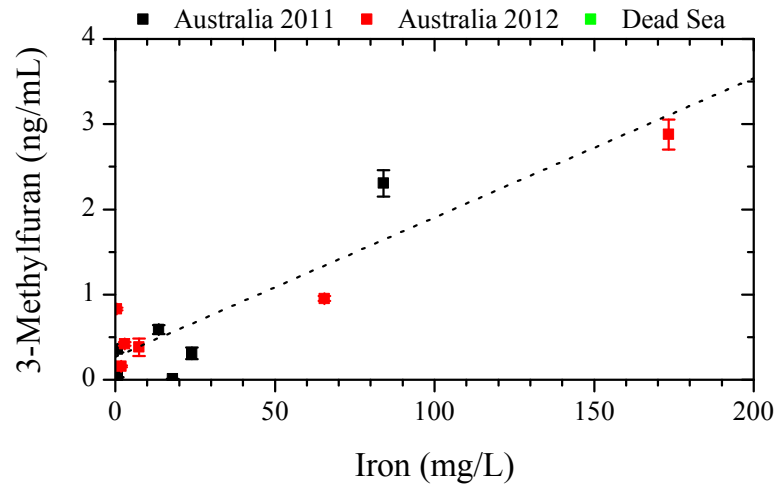

B

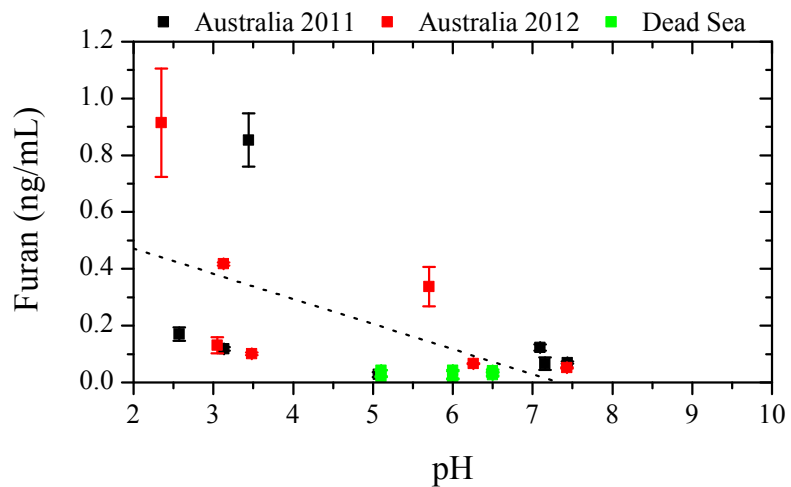

D

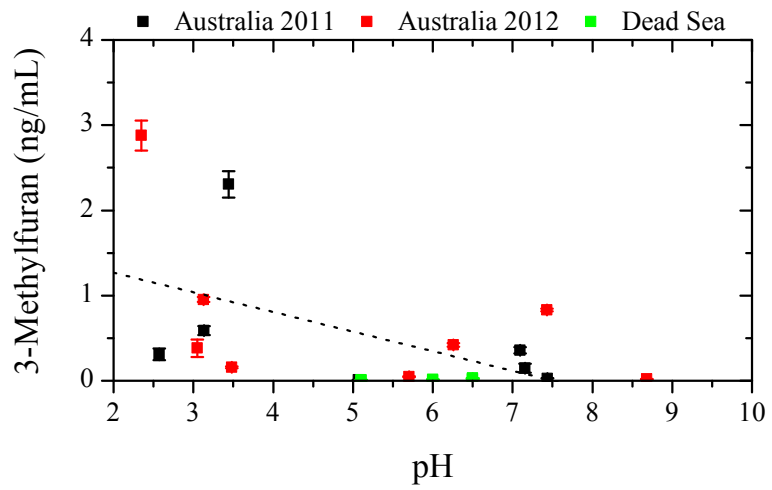

Figure 9. Furan emissions dependent on (A) iron concentration, (B) pH and (C) organic carbon content in water samples (Australia 2011: black; Australia 2012: red; Dead Sea 2012: blue). Data points represent mean values with error bars indicating standard deviations from triplicate measurements.

the emission of several furan derivatives was observed from sediment and water samples of hypersaline environments.

Total yields of $0.6 \%$ of furan from catechol using the bispidine $\mathrm{Fe}^{2+}$ complex are comparable to previous studies using $\mathrm{Fe}^{3+}$ sulfate, but the turnover numbers of the $\mathrm{Fe}^{2+}$ complex are eight times higher than those of the $\mathrm{Fe}^{3+}$ salt. The main advantage of the bispidine $\mathrm{Fe}^{2+}$ complex for this kind of model reaction is the defined and well known coordination sphere which can be used in theoretical studies to calculate possible intermediates and reaction pathways.

Important parameters of the model reactions like iron concentration and $\mathrm{pH}$ can be projected on natural sediment and water samples as higher iron concentration and lower $\mathrm{pH}$ favoured furan emissions. Additionally, many geochemical parameters of Australian salt lakes and the Dead Sea were acquired and the emission of furan derivatives from these environments was discussed for the first time. These include various methylated and higher alkylated furans as well as 3chlorofuran and 3-bromofuran. To our knowledge this is the first finding of 3-chlorofuran in natural samples while bromofuran has only been reported so far from onion bulbs incubated with Erwinia carotovora (Prithiviraj et al., 2004).

Furthermore, our results show that the sediments of salt lakes are a natural source for furanoic compounds which can contribute to the atmospheric formation of ultra-fine parti- cles (Gómez Alvarez et al., 2009) as observed around the Australian salt lakes and hence have an impact on the local climate (Junkermann et al., 2009).

\section{The Supplement related to this article is available online at doi:10.5194/bg-11-2871-2014-supplement.}

Acknowledgements. We thank Marie Krause, Tobias Sattler, Ines Mulder, Sabine Studenroth and Stefan Huber for valuable discussions, Christian Scholz, Stefan and Silvia Rheinberger for instrumental and analytical support and everyone involved in the expeditions to Australia and Israel. This work was supported by the German Research Foundation (DFG) in the context of the Research Unit 763.

Edited by: M. Dai

\section{References}

Atkinson, R., Aschmann, S. M., and Carter, W. P. L.: Kinetics of the reactions of $\mathrm{O}_{3}$ and $\mathrm{OH}$ radicals with furan and thiophene at $298 \pm 2 \mathrm{~K}$, Int. J. Chem. Kinet., 15, 51-61, doi:10.1002/kin.550150106, 1983. 
Atkinson, R., Aschmann, S. M., Tuazon, E. C., Arey, J., and Zielinska, B.: Formation of 3-methylfuran from the gas-phase reaction of $\mathrm{OH}$ radicals with isoprene and the rate constant for its reaction with the $\mathrm{OH}$ radical, Int. J. Chem. Kinet., 21, 593-604, doi:10.1002/kin.550210709, 1989.

Berndt, T. and Böge, O.: Gas-phase reaction of $\mathrm{OH}$ radicals with benzene: products and mechanism, Phys. Chem. Chem. Phys., 3, 4946-4956, doi:10.1039/B106667F, 2001.

Berndt, T., Böge, O., and Rolle, W.: Products of the gas-phase reactions of $\mathrm{NO}_{3}$ radicals with furan and tetramethylfuran, Environ. Sci. Technol., 31, 1157-1162, doi:10.1021/es960669z, 1997.

Bierbach, A., Barnes, I., and Becker, K. H.: Product and kinetic study of the $\mathrm{OH}$-initiated gas-phase oxidation of furan, 2methylfuran and furanaldehydes at $\approx 300 \mathrm{~K}$, Atmos. Environ., 29, 2651-2660, doi:10.1016/1352-2310(95)00096-H, 1995.

Börzel, H., Comba, P., Hagen, K. S., Lampeka, Y. D., Lienke, A., Linti, G., Merz, M., Pritzkow, H., and Tsymbal, L. V.: Iron coordination chemistry with tetra-, penta- and hexadentate bispidine-type ligands, Inorg. Chim. Acta, 337, 407-419, doi:10.1016/S0020-1693(02)01100-3, 2002.

Bowen, B. B. and Benison, K. C.: Geochemical characteristics of naturally acid and alkaline saline lakes in southern Western Australia, Appl. Geochem., 24, 268-284, doi:10.1016/j.apgeochem.2008.11.013, 2009.

Bukowski, M. R., Comba, P., Lienke, A., Limberg, C., de Laorden, C. L., Mas-Balleste, R., Merz, M., and Que, L.: Catalytic epoxidation and 1,2-dihydroxylation of olefins with bispidineiron(II) $/ \mathrm{H}_{2} \mathrm{O}_{2}$ systems, Angew. Chem. Int. Edit., 45, 3446-3449, doi:10.1002/anie.200504357, 2006.

Cabañas, B., Villanueva, F., Martín, P., Baeza, M. T., Salgado, S., and Jiménez, E.: Study of reaction processes of furan and some furan derivatives initiated by $\mathrm{Cl}$ atoms, Atmos. Environ., 39, 1935-1944, doi:10.1016/j.atmosenv.2004.12.013, 2005.

Carter, W. P. L.: Updated Maximum Incremental Reactivity Scale and Hydrocarbon Bin Reactivities for Regulatory Applications, California Air Resources Board Contract 07-339, 2009.

Cheburkin, A. K., Frei, R., and Shotyk, W.: An energy-dispersive miniprobe multielement analyzer (EMMA) for direct analysis of trace elements and chemical age dating of single mineral grains, Chem. Geol., 135, 75-87, doi:10.1016/S0009-2541(96)00105-2, 1997.

Christian, T. J., Kleiss, B., Yokelson, R. J., Holzinger, R., Crutzen, P. J., Hao, W. M., Saharjo, B. H., and Ward, D. E.: Comprehensive laboratory measurements of biomassburning emissions: 1. Emissions from Indonesian, African, and other fuels, J. Geophys. Res.-Atmos., 108, 4719, doi:10.1029/2003JD003704, 2003.

Comba, P., Fukuzumi, S., Kotani, H., and Wunderlich, S.: Electrontransfer properties of an efficient nonheme iron oxidation catalyst with a tetradentate bispidine ligand, Angew. Chem. Int. Edit., 49, 2622-2625, doi:10.1002/anie.200904427, 2010.

Comba, P., Wadepohl, H., and Wunderlich, S.: Oxidation versus dioxygenation of catechol: the iron-bispidine system, Eur. J. Inorg. Chem., 2011, 5242-5249, doi:10.1002/ejic.201100802, 2011

Cooper, W. J., Zika, R. G., Petasne, R. G., and Plane, J. M. C.: Photochemical formation of $\mathrm{H}_{2} \mathrm{O}_{2}$ in natural-waters exposed to sunlight, Environ. Sci. Technol., 22, 1156-1160, doi:10.1021/es00175a004, 1988.
Degens, B. and Shand, P.: Assessment of Acidic Saline Groundwater Hazard in the Western Australian Wheatbelt: Yarra Yarra, Blackwood and South Coast, CSIRO, 2010.

Deng, Y. W. and Zuo, Y. G.: Factors affecting the levels of hydrogen peroxide in rainwater, Atmos. Environ., 33, 1469-1478, doi:10.1016/S1352-2310(98)00239-8, 1999.

Dumdei, B. E., Kenny, D. V., Shepson, P. B., Kleindienst, T. E., Nero, C. M., Cupitt, L. T., and Claxton, L. D.: MS/MS analysis of the products of toluene photooxidation and measurement of their mutagenic activity, Environ. Sci. Technol., 22, 1493-1498, doi:10.1021/es00177a017, 1988.

Gómez Alvarez, E., Borrás, E., Viidanoja, J., and Hjorth, J.: Unsaturated dicarbonyl products from the $\mathrm{OH}$-initiated photo-oxidation of furan, 2-methylfuran and 3-methylfuran, Atmos. Environ., 43, 1603-1612, doi:10.1016/j.atmosenv.2008.12.019, 2009.

Grebel, J. E., Pignatello, J. J., and Mitch, W. A.: Effect of halide ions and carbonates on organic contaminant degradation by hydroxyl radical-based advanced oxidation processes in saline waters, Environ. Sci. Technol., 44, 6822-6828, doi:10.1021/es1010225, 2010.

Gu, C. L., Rynard, C. M., Hendry, D. G., and Mill, T.: Hydroxyl radical oxidation of isoprene, Environ. Sci. Technol., 19, 151155, doi:10.1021/es00132a007, 1985.

Gunz, D. W. and Hoffmann, M. R.: Atmospheric chemistry of peroxides - a review, Atmos. Environ. A-Gen., 24, 1601-1633, 1990.

Haber, F. and Weiss, J.: Über die Katalyse des Hydroperoxydes, Naturwissenschaften, 20, 948-950, doi:10.1007/BF01504715, 1932.

Hempfling, R. and Schulten, H. R.: Chemical characterization of the organic matter in forest soils by Curie point pyrolysisGC/MS and pyrolysis-field ionization mass spectrometry, Org. Geochem., 15, 131-145, doi:10.1016/0146-6380(90)90078-E, 1990.

Holla, R.: Reactive halogen species above salt lakes and salt pans, $\mathrm{PhD}$ thesis, 2013.

Huber, S. G., Wunderlich, S., Schöler, H. F., and Williams, J.: Natural abiotic formation of furans in soil, Environ. Sci. Technol., 44, 5799-5804, doi:10.1021/es100704g, 2010.

Isidorov, V. and Jdanova, M.: Volatile organic compounds from leaves litter, Chemosphere, 48, 975-979, doi:10.1016/S00456535(02)00074-7, 2002.

Isidorov, V. A., Zenkevich, I. G., and Ioffe, B. V.: Volatile organic compounds in the atmosphere of forests, Atmos. Environ., 19, 1-8, doi:10.1016/0004-6981(85)90131-3, 1985.

Jordan, E. D., Hsieh, T. C. Y., and Fischer, N. H.: Volatiles from litter and soil associated with Ceratiola ericoides, Phytochemistry, 33, 299-302, doi:10.1016/0031-9422(93)85507-N, 1993.

Junkermann, W., Hacker, J., Lyons, T., and Nair, U.: Land use change suppresses precipitation, Atmos. Chem. Phys., 9, 65316539, doi:10.5194/acp-9-6531-2009, 2009.

Kamilli, K., Ofner, J., Sattler, T., Krause, T., Zetzsch, C., and Held, A.: Particle formation above natural and simulated salt lakes, Geophys. Res. Abstr. - EGU General Assembly 2013, 15 pp., 2013.

Khain, A., Rosenfeld, D., and Pokrovsky, A.: Aerosol impact on the dynamics and microphysics of deep convective clouds, Q. J. Roy. Meteor. Soc., 131, 2639-2663, doi:10.1256/qj.04.62, 2005. 
Kind, I., Berndt, T., Böge, O., and Rolle, W.: Gas-phase rate constants for the reaction of $\mathrm{NO}_{3}$ radicals with furan and methyl-substituted furans, Chem. Phys. Lett., 256, 679-683, doi:10.1016/0009-2614(96)00513-1, 1996.

Leff, J. W. and Fierer, N.: Volatile organic compound (VOC) emissions from soil and litter samples, Soil Biol. Biochem., 40, 16291636, doi:10.1016/j.soilbio.2008.01.018, 2008.

Matveev, V., Peleg, M., Rosen, D., Tov-Alper, D. S., Hebestreit, K., Stutz, J., Platt, U., Blake, D., and Luria, M.: Bromine oxideozone interaction over the Dead Sea, J. Geophys. Res.-Atmos., 106, 10375-10387, doi:10.1029/2000JD900611, 2001.

M'Hemdi, A., Dbira, B., Abdelhedi, R., Brillas, E., and Ammar, S.: Mineralization of catechol by Fenton and photoFenton processes, CLEAN-Soil, Air, Water, 40, 878-885, doi:10.1002/clen.201100376, 2012.

Mulder, I., Huber, S. G., Krause, T., Zetzsch, C., Kotte, K., Dultz, S., and Schöler, H. F.: A new purge and trap headspace technique to analyse low volatile compounds from fluid inclusions of rocks and minerals, Chem. Geol., 358, 148-155, doi:10.1016/j.chemgeo.2013.09.003, 2013.

Müller, G. and Gastner, M.: The "Karbonat-Bombe", a simple device for the determination of carbonate content in sediment, soils, and other materials, Neues Jb. Miner. Monat., 10, 466-469, doi:10.013/epic.27884, 1971

Ofner, J., Kamilli, K. A., Held, A., Lendl, B., and Zetzsch, C.: Halogen-induced organic aerosol (XOA): a study on ultra-fine particle formation and time-resolved chemical characterization, Faraday Discuss., 165, 135-149, doi:10.1039/C3FD00093A, 2013

Ohta, T.: Furan ring formation in $\mathrm{OH}$-initiated photooxidation of 1,3-butadiene and cis-1,3-pentadiene, B. Chem. Soc. Jpn., 57, 960-966, 1984.

Pierce, J. R. and Adams, P. J.: Efficiency of cloud condensation nuclei formation from ultrafine particles, Atmos. Chem. Phys., 7, 1367-1379, doi:10.5194/acp-7-1367-2007, 2007.

Prithiviraj, B., Vikram, A., Kushalappa, A. C., and Yaylayan, V.: Volatile metabolite profiling for the discrimination of onion bulbs infected by Erwinia carotovora ssp. carotovora, Fusarium oxysporum and Botrytis allii, Eur. J. Plant Pathol., 110, 371-377, doi:10.1023/B:EJPP.0000021058.81491.f8, 2004.

Remucal, C. K. and Sedlak, D. L.: The Role of iron coordination in the production of reactive oxidants from ferrous iron oxidation by oxygen and hydrogen peroxide, in: Aquatic Redox Chemistry, ACS Symposium Series, American Chemical Society, 177-197, 2011.

Risholm-Sundman, M., Lundgren, M., Vestin, E., and Herder, P.: Emissions of acetic acid and other volatile organic compounds from different species of solid wood, Holz Roh. Werkst., 56, 125-129, doi:10.1007/s001070050282, 1998.
Rogge, W. F., Hildemann, L. M., Mazurek, M. A., Cass, G. R., and Simoneit, B. R. T.: Sources of fine organic aerosol. 1. Charbroilers and meat cooking operations, Environ. Sci. Technol., 25, 1112-1125, doi:10.1021/es00018a015, 1991.

Shand, P., Degens, B, Western Australia Dept. of W., Western Australia Dept. of Agriculture and F., National Action Plan for Salinity and Water Q., and Cooperative Research Centre for Landscape Environments and Mineral E., Avon Catchment Acidic Groundwater: Geochemical Risk Assessment, Crc LEME, 2008.

Shepson, P. B., Edney, E. O., and Corse, E. W.: Ring fragmentation reactions in the photooxidations of toluene and o-xylene, J. Phys. Chem., 88, 4122-4126, doi:10.1021/j150662a053, 1984.

Spilker, R. and Grutzmacher, H.-F.: Isomerization and fragmentation of methylfuran ions and pyran ions in the gas phase, Org. Mass Spectrom., 21, 459-466, doi:10.1002/oms.1210210803, 1986.

Studenroth, S., Huber, S. G., Kotte, K., and Schöler, H. F.: Natural abiotic formation of oxalic acid in soils: results from aromatic model compounds and soil samples, Environ. Sci. Technol., 47, 1323-1329, doi:10.1021/es304208a, 2013.

Stutz, J., Ackermann, R., Fast, J. D., and Barrie, L.: Atmospheric reactive chlorine and bromine at the Great Salt Lake, Utah, Geophys. Res. Lett., 29, 18-11-18-14, doi:10.1029/2002GL014812, 2002.

Villanueva, F., Cabañas, B., Monedero, E., Salgado, S., Bejan, I., and Martín, P.: Atmospheric degradation of alkylfurans with chlorine atoms: product and mechanistic study, Atmos. Environ., 43, 2804-2813, doi:10.1016/j.atmosenv.2009.02.030, 2009.

Williams, W. D.: Salinisation: a major threat to water resources in the arid and semi-arid regions of the world, Lakes \& Reservoirs: Research \& Management, 4, 85-91, doi:10.1046/j.14401770.1999.00089.x, 1999.

Zhang, H.-Z., Kasibhatla, S., Kuemmerle, J., Kemnitzer, W., OllisMason, K., Qiu, L., Crogan-Grundy, C., Tseng, B., Drewe, J., and Cai, S. X.: Discovery and structure-activity relationship of 3-aryl-5-aryl-1,2,4-oxadiazoles as a new series of apoptosis inducers and potential anticancer agents, J. Med. Chem., 48, 52155223, doi:10.1021/jm050292k, 2005.

Zhang, W. and Du, B.: Products and mechanism of the Cl-initiated atmospheric oxidation of furan: a theoretical study, Comput. Theor. Chem., 963, 348-356, doi:10.1029/2004JD004993, 2011.

Zhang, Z., Xiang, Q., Glatt, H., Platt, K. L., Goldstein, B. D., and Witz, G.: Studies on pathways of ring opening of benzene in a Fenton system, Free Radic. Biol. Med., 18, 411-419, 1995.

Zingler, J. and Platt, U.: Iodine oxide in the Dead Sea Valley: evidence for inorganic sources of boundary layer IO, J. Geophys Res.-Atmos., 110, D07307, doi:10.1029/2004JD004993, 2005. 